\title{
Inclusion of Anastrepha ludens fruit fly pupae in poultry rations added with digestive enzymes and yeast
}

Inclusión de pupas de mosca de la fruta Anastrepha ludens en raciones para aves adicionadas con enzimas digestivas y levadura

Inclusão de pupas de mosca-das-frutas Anastrepha ludens em rações avícolas com adição de enzimas digestivas e levedura

José Alfonso López-García ${ }^{1}$; (c)

Julieta Grajales-Conesa ${ }^{1}$ (a) (1)

Víctor Jesús Albores-Flores ${ }^{1 *}$ (중 (10)

Rodolfo Torres de los Santos ${ }^{2}$; (10)

Luis Alejandro Ramón-Javier ${ }^{1}$ : (1)

Liliana Carolina Cordova-Albores ${ }^{3}$ : (i)

Rev. Fac. Agron. (LUZ). 2022, 39(1): e223903

ISSN 2477-9407

DOI: https://doi.org/10.47280/RevFacAgron(LUZ).v39.n1.03

\section{Animal Production}

Associate editor: Ing. Agr. MSc. Juan Vergara

\begin{abstract}
'Instituto de Biociencias. Universidad Autónoma de Chiapas. Boulevard Príncipe Akishino s/n. Col. Solidaridad 2000. Tapachula, 30798, Chiapas, México. Tel. y fax. 529626225723 ${ }^{2}$ Universidad Autónoma De Tamaulipas. Unidad Académica Multidisciplinaria Mante. Blvd Enrique Cárdenas González \# 1201 PTE. Col.. Jardín CP 89840 Ciudad Mante, Tamps. ${ }^{3}$ Escuela de Agronomía. Universidad de La Salle Bajío. Av. Universidad 602, Col. Lomas del Campestre. C. P. 37150. León Guanajuato, México.
\end{abstract}

Received: 20-10-2020

Accepted: 20-09-2021

Published: 16-12-2021

\section{Keywords:}

Food

Probiotics

Proteases

Protein by-products

\begin{abstract}
In Mexico, poultry meat represents $24,8 \%$ of the protein consumed. In the search for protein sources that meet this demand, the use of insects has been found to be of potential interest. In order to reduce the effect of the components that affect the absorption of nutrients, additives such as digestive enzymes and microorganisms have been used. The objective of this study was to determine the weight gain of birds (Gallus gallus domesticus) fed with diets formulated with fruit fly pupa (Anastrepha ludens), digestive enzymes and yeast (Saccharomyces cerevisiae). Groups were established completely at random with different inclusions of fly pupae $0 \%, 12 \%, 14 \%$ and $16 \%$ respectively and significant differences were found $(\mathrm{p}<0.05)$. The group with $14 \%$ protein was the one with the greatest weight gain during the experiment and the second phase used digestive enzymes and Saccharomyces cerevisiae and it was found that treatment 3: $14 \%$ of Anastrepha ludens pupa $+200 \mathrm{IU}$ of Protease +1502 IU of Amylase +80 IU of Cellulase +62 IU of Lipase $+40 \mathrm{IU}$ of Pectinase $+8.88 \times 109$ CFU S. cerevisiae / $100 \mathrm{~g}$ of feed showed differences $(p<0.05)$ and the best results in the weight gain of the birds. It is concluded that inclusion of $14 \%$ of fly pupa in rations promotes the weight gain of Gallus gallus domesticus with the addition of digestive enzymes and S. cerevisiae.
\end{abstract}




\section{2-6 Rev. Fac. Agron. (LUZ). 2022, 39(1): e223903. January - March. ISSN 2477-9407.}

\section{Resumen}

En México la carne de aves representa el 24,8 \% de la proteina consumida. En la búsqueda de fuentes proteicas que cubran esa demanda se han encontrado con interés potencial la utilización de insectos. Con la finalidad de reducir el efecto de los componentes que afectan la absorción de nutrientes se han utilizado aditivos como enzimas digestivas y microorganismos. El objetivo del presente estudio fue determinar la ganancia de peso de aves (Gallus gallus domesticus) alimentadas con dietas formuladas con pupa de mosca de la fruta (Anastrepha ludens), enzimas digestivas y levadura (Saccharomyces cerevisiae). Se establecieron grupos completamente al azar con diferentes inclusiones de pupa de mosca $0 \%, 12 \%, 14$ $\%$ y $16 \%$ respectivamente y se encontraron diferencias significativas $(p<0,05)$. El grupo con $14 \%$ de proteína fue el que mayor ganancia de peso tuvo durante el experimento y la segunda fase se utilizaron enzimas digestivas y $S$. cerevisiae y se encontró que el tratamiento 3 : $14 \%$ de pupa de Anastrepha ludens +200 UI de Proteasa +1502 UI de Amilasa +80 UI de Celulasa +62 UI de Lipasa +40 UI de Pectinasa + $8,88 \times 10^{9} \mathrm{UFC}$ S. cerevisiae / $100 \mathrm{~g}$ de alimento mostró diferencias $(\mathrm{p}<0,05)$ y los mejores resultados en la ganancia de peso de las aves. Se concluye que la inclusión de $14 \%$ de pupa de mosca en raciones promueve para ganancia de peso de Gallus gallus domesticus con la adición de enzimas digestivas y $S$. cerevisiae.

Palabras clave: Alimentación, probióticos, proteasas, subproductos proteicos.

\section{Resumo}

No México, a carne de frango representa $24,8 \%$ da proteína consumida. Na busca por fontes proteicas que atendam a essa demanda, o uso de insetos tem se mostrado de potencial interesse. Para reduzir o efeito dos componentes que afetam a absorção de nutrientes, aditivos como enzimas digestivas e microrganismos têm sido utilizados. O objetivo deste trabalho foi determinar o ganho de peso de aves (Gallus gallus domesticus) alimentadas com dietas formuladas com pupa de mosca-das-frutas (Anastrepha ludens), enzimas digestivas e levedura (Saccharomyces cerevisiae). Os grupos foram estabelecidos de forma completamente aleatória com diferentes inclusões de pupas de mosca $0 \%, 12 \%, 14 \%$ e $16 \%$, respetivamente, e diferenças significativas foram encontradas $(\mathrm{p}<0,05)$. O grupo com $14 \%$ de proteína foi o que apresentou maior ganho de peso durante o experimento e a segunda fase utilizou enzimas digestivas e Saccharomyces cerevisiae e verificou-se que o tratamento 3:14\% de Anastrepha ludens pupa + 200 UI de Protease +1502 UI de Amilase +80 UI de Celulase +62 UI de Lipase +40 UI de Pectinase $+8,88 \times 109$ UFC de S. cerevisiae / 100 $\mathrm{g}$ de ração apresentaram diferenças $(\mathrm{p}<0,05)$ e os melhores resultados no ganho de peso das aves. Conclui-se que a inclusão de $14 \%$ de pupa de mosca nas rações promove o ganho de peso de Gallus gallus domesticus com a adição de enzimas digestivas e $S$. cerevisiae.

Palavras-chave: Alimentos, probáticos, protéases, subprodutos de proteínas.

\section{Introduction}

The poultry industry is one of the most important livestock activities in Latin American countries (FAO, 2015). In Mexico, it participates with $24.8 \%$ of animal protein consumed (UNA, 2015;
SAGARPA, 2015); particularly in rural areas, backyard poultry farming is the main source of animal protein (egg and meat) for human consumption (SAGARPA, 2007; SEDESOL, 2010).

In commercial poultry farming, soybean meal, meat and fish are the primary sources of protein (FAO, 2013), however, in backyard conditions, the feeding is made, primarily, based on grains (corn, sorghum) which on many occasions, do not cover the protein needs of the birds (Medina, 2012). Such deficiency limits the productive and reproductive levels (Sánchez, 2013). In addition, since corn is the base of the Mexican diet, a food competition is established for the same input (SAGARPA, 2015; USDA, 2015). On the other hand, cerealbased poultry rations contain non-starch polysaccharides (NAP) such as cellulose and hemicellulose, which affect the absorption of nutrients, causing deficiencies in animal nutrition and development (Choct et al., 2010).

In the search for alternative sources of protein useful for animal feed and available in the environment, a large number of research works have been carried out (SEDESOL, 2010; FAO, 2015). In this sense, due to the quantity and quality of protein that insects have (Veldkamp et al., 2012; Sancho et al., 2015), they can be an alternative for feeding birds, with the advantage that birds naturally ingest adult insects, larvae, and pupae (Hwangbo et al., 2009). These contain amounts of protein and fat comparable with commercial protein meal (Barroso et al., 2014; Józefiak and Engberg, 2015), in addition, that the composition of chitin (exoskeleton) has been found to favor the immune response, the growth of beneficial bacteria and inhibits the growth of pathogenic microorganisms (Van Huis et al., 2013).

Likewise, the use of biological additives (microorganisms and enzymes) in the animal diet improves the availability of nutrients (Kiarie, 2013), within these there are yeasts, mainly Saccharomyces cerevisiae that has been used in different species such as bovines, pigs and poultry as an inhibitor of pathogens such as Salmonella sp., digestion enhancers, promoting the action of digestive enzymes and stimulating immunity (Ogbuewu et al., 2018). Likewise, they favor an increase in the size and number of intestinal villi, and maintain a better state of immunocompentence and prevent colonization of the intestine by Salmonella sp. (Hassanein and Soliman, 2010; Adebiyi et al., 2012, Kiros, et al., 2019).

For their part, exogenous enzymes help to hydrolyze molecules facilitating the digestion of food and producing a better development by birds (Bedford and Patridge, 2001; Méndez et al., 2009). Enzymes can be classified according to polygastric or monogastric species and in the latter case it is where the catalytic biomolecules that normally cannot be metabolized by birds, although due to their microbiota, have been used recently. They promote better digestion, improve intestinal transit and modify the consistency of the stool allowing greater digestibility of the nutrients. It has also been found that in young birds these enzymes promote a better productive performance of the same (Mulisa, 2017). Therefore, the objective of this work was to determine the weight gain of birds (Gallus gallus domesticus) fed with diets formulated with fruit fly pupa (Anastrepha ludens), digestive enzymes and yeast (S. cerevisiae).

\section{Materials and methods}

The work was carried out at the "Ayol" agroecological farm $\left(14^{\circ} 49^{\prime} 45^{\prime \prime} \mathrm{N}, 92^{\circ} 17^{\prime} 47^{\prime \prime} \mathrm{W}\right)$ located in Tapachula, Chiapas and in the researchLlaboratorio de Investigación del Instituto de Biociencias de la Universidad Autónoma de Chiapas (UNACH). 
The experiment was carried out in two phases. Phase 1: To determine the effect of the fly pupa (A. ludens) and biological additives (digestive enzymes and $S$. cerevisiae) on the development of Gallus gallus domesticus fed with isoprotein rations designed for this purpose, the following experiment was established: Isoprotein rations were designed according to the nutritional requirements of the birds (NRC, 1994) with A. ludens pupa as a non-conventional protein source. The rations were made with corn, commercial kernel and fly pupa, whose proximal chemical content was analyzed by quantifying crude protein, crude fat, acid detergent fiber, moisture, ash and nitrogen-free extract (NMX-f-083- 1986, NMX-f-066-s-1978, NMXf-089-s-1978, NOM-F-68-S-1980, NOM-F-90-S-1978.) (table 1).

Table 1. Proximal chemical analysis of ingredients $\left(\mathrm{g} \cdot 100 \mathrm{~g}^{-1}\right)$.

\begin{tabular}{llll}
\hline Determination & Maice & Fly pupa & Core \\
\hline Crude protein & $8.9 \pm 0.1$ & $49.21 \pm 0.3$ & $19.78 \pm 0.17$ \\
Crude fat & $2.40 \pm 0.21$ & $1.48 \pm 0.38$ & $2.74 \pm 0.1$ \\
Fiber & $4.49 \pm 0.37$ & $0.0025 \pm 0.005$ & $4.94 \pm 0.12$ \\
Ash & $0.87 \pm 0.14$ & $8.53 \pm 0.27$ & $5.6 \pm 0.16$ \\
NFE $^{1}$ & $83.27 \pm 0.2$ & $40.85 \pm 0.24$ & $66.92 \pm 0.13$
\end{tabular}

Values on a dry basis. 1Nitrogen-free extract

To evaluate the weight gain of the birds fed these rations, 100 male individuals were assigned to treatments in 4 groups of birds of the Sussex line of one month of age and an average weight of $415 \pm$ $0.1 \mathrm{~g}$ with 25 individuals each. In a group in a completely randomized design with 4 repetitions (one bird as an experimental unit and 24 more birds as a repetition), the weight gain and mortality rate were measured for a period of 30 days.

Table 2. Ingredients and nutritional composition in the final stage rations.

\begin{tabular}{crrrr}
\hline Ingredients \% & $\begin{array}{c}\text { Control } \\
\text { treatment }\end{array}$ & $\begin{array}{c}\text { Treatment } \\
\mathbf{1}\end{array}$ & $\begin{array}{c}\text { Treatment } \\
\mathbf{2}\end{array}$ & $\begin{array}{c}\text { Treatment } \\
\mathbf{3}\end{array}$ \\
\hline Fly pupa & 0 & 12 & 14 & 16 \\
Maice & 64 & 68 & 74 & 79 \\
Core & 36 & 20 & 12 & 7 \\
\hline \multicolumn{5}{c}{ Valor nutricional calculado } \\
Protein & 14.43 & 14.43 & 14.36 & 14.30 \\
Fat & 2.38 & 2.14 & 2.09 & 2.06 \\
Fiber & 4.34 & 3.67 & 3.55 & 3.44 \\
Humedity & 9.18 & 9.44 & 9.48 & 9.53 \\
Ash & 3.55 & 2.48 & 2.27 & 2.07 \\
Energy ${ }^{1}(\mathrm{~J})$ & $1,106.58$ & $1,135.37$ & $1,141.89$ & $1,148.09$ \\
\hline
\end{tabular}

${ }^{1}$ Energy in joules. $100 \mathrm{~g}^{-1}$ of feed

Management: The birds were previously adapted to the rations with the gradual inclusion of the diet and immunized against enzootic diseases of the region (Pasteurellosis and Newcastle).

The first phase of the experiment concluded with the identification of the ration that promoted the greatest weight gain in the birds $(p<0.05)$ (table 3). This made it possible to know the degree of inclusion of the alternative protein source in isoprotein rations in order to design in a second phase rations with pupae of A. ludens added with different proportions of a biological additive: Protease 225 IU, Amylase 1690 IU, Cellulase 90 IU, Lipase 70 IU, Pectinase
$45 \mathrm{IU}$; S. cerevisiae 1.0x1010 CFU per $\mathrm{g}$ of additive, and the weight gain and mortality rate were evaluated with a completely randomized design and $4 \times 2$ factorial arrangement (treatment and sex): T0: ration without biological additive, T1: $0.044 \%$; T2: $0.066 \%$; T3: 0.088 $\%$, according to the nutritional requirements (table 4 ) of the birds during 69 days. For this, 80 female and male birds (Gallus gallus domesticus) one week old and an average weight of $94 \pm 0.7 \mathrm{~g}$ were used, randomly distributed and included in each treatment ( 1 bird as an experimental unit and 19 birds as a repetition).

The statistical analysis consisted for the first and second phases of the experiment in an analysis of variance to determine the differences between the means of the treatments and a contrast of means by Tukey to identify the different treatment (s) with a confidence of 95 $\%(\mathrm{p}<0.05)$ with the statistical software Statgraphics Centurion XVI MR.

\section{Results and discussion}

The proximal chemical composition of the unconventional protein source (A. ludens) used for the preparation of isoprotein rations is shown in table 3. The proximal chemical composition of a wide variety of insects has been described in advance (Kouřimská and Adámková , 2016; Oonincx and Finke, 2020), but not the pupa of $A$. ludens, which so far lacks studies that describe its nutritional content. Pretorius (2011) found that the nutritional content of Musca domestica pupa is close to $60 \%$ protein, which is higher than that found in the present work. On the other hand, Rumpold and Schlüter (2013), determined the nutritional composition of more than 200 insects and found that those of the order Diptera have a percentage range of $49.48 \pm 13.61$ of protein, lower in the reported fiber content $13.56 \pm 3.81$ and fat $22.75 \pm 10.86$; noting that $A$. ludens is a potential protein source to be used in domestic animal feed.

The weight gain of the birds between the treatments was different $(\mathrm{P} \leq 0.05)$ with the inclusion of $12 \%, 14 \%$ and $16 \%$ of pupa in the diet and the control group (table 4).

The highest weight gain of the birds was obtained by including 14 $\%$ of $A$. ludens pupae in the diet with a mean gain of $857.30 \pm 112.54$ $\mathrm{g}$ during the evaluation period and a zero mortality rate.

Pretorius (2011) determined that with an inclusion of $10 \%$ of Musca domestica in a conventional diet for birds, the best results are obtained in weight gain and efficiency in feed conversion, although the range extends to $25 \%$ with favorable results. The inclusion of insects in the diet improved weight gain since according to Hwangbo et al. (2009) provides a positive effect due to their digestibility and nutritional value. According to De Marco et al. (2015) and Schiavone et al. (2017) the flour of Tenebrio molitor and Hemetia illucens respectively, are valuable sources of metabolizable energy and digestible amino acids that birds can take advantage of together with their rapid digestive process. Bovera et al. (2016) used flour from Tenebrio molitor in the larval stage and found that chickens develop better when insects are included as a source of protein, similar to this study. The source of fiber, the type and age of the birds influence the response of the birds to their diet (González et al. 2010; Oonincx and Finke, 2020).

The treatments evaluated with the inclusion of biological additives such as enzymes and yeasts in the diet prepared with $14 \%$ of $A$. ludens (table 3 ) were different $(\mathrm{P} \leq 0.05)$. The treatment 3 with biological additive (200 IU of Proteases, 1502 IU of Amylases, 80 IU of Cellulase, 62 IU of Lipase, 40 IU of Pectinase, 8.88x109 CFU 
4-6| Rev. Fac. Agron. (LUZ). 2022, 39(1): e223903. January - March. ISSN 2477-9407.

Table 3. Nutritional composition of the rations $(\mathrm{g} \square 100 \square \mathrm{g}$ ) with the biological additive

\begin{tabular}{|c|c|c|c|c|c|c|}
\hline Nutrient & Star & Development & End & T1 & T2 & T3 \\
\hline Protein & 20.1 & 17 & 14.36 & & & \\
\hline Fat & 2.27 & 2.19 & 2.09 & & & \\
\hline Fiber & 3.80 & 3.67 & 3.55 & & & \\
\hline Moisture & 9.19 & 9.35 & 9.48 & & & \\
\hline Ash & 4.77 & 3.44 & 2.27 & & & \\
\hline $\operatorname{AME}^{1}(\mathrm{~J})$ & $1,001.98$ & $1,076.96$ & $1,141.89$ & & & \\
\hline \multicolumn{7}{|l|}{ Enzymes $^{2}$} \\
\hline Protease & & & & 100 & 150 & 200 \\
\hline Amylase & & & & 751 & 1,127 & 1,502 \\
\hline Cellulase & & & & 40 & 60 & 80 \\
\hline Lipase & & & & 31 & 47 & 62 \\
\hline Pectinase & & & & 20 & 30 & 40 \\
\hline S. cerevisiae $(\mathrm{CFU})^{3}$ & & & & $4,44 \times 10^{9}$ & $6,66 \times 10^{9}$ & $8,88 \times 10$ \\
\hline
\end{tabular}

${ }^{1}$ AME. apparent metabolizable energy (Joules). ${ }^{2}$ Units of digestive enzymes. ${ }^{3}$ Colony-forming unit according to the Alka Rumen NRV commercial product information, NORVET ${ }^{\mathrm{MR}}$ laboratories.

Table 4. ANOVA Weight gain of birds with isoprotein rations.

\begin{tabular}{ll}
\hline Groups & Weight gain $(\mathrm{g})$ \\
\hline Witness & $757.67 \pm 125.93^{\mathrm{bc}}$ \\
T1 & $524.00 \pm 71.06^{\mathrm{c}}$ \\
T2 & $857.33 \pm 112.54^{\mathrm{a}}$ \\
T3 & $653.33 \pm 140.79^{\mathrm{ab}}$ \\
\hline
\end{tabular}

$\overline{a, b, c}$ Different literals mean significant differences $(\mathrm{p}<0.05)$.

of $S$. cerevisiae) had the greatest positive effect on the weight gain of birds, with an average of 1,902.09 $\mathrm{g}$ with respect to the control group that had 1,699.99 $\mathrm{g}$ of gain and the males had a significantly greater gain than that of the females $(\mathrm{P} \leq 0.05)$ (table 5 ). However, the interaction between the additive and sex did not show differences (table 6 and 7), although Hristakieva et al. (2014) mention that the sex of the birds is decisive in their development as the males have a higher metabolic rate. For their part, enzymes and yeasts improved the digestibility of nutrients through hydrolytic processes, which birds are not capable of digesting (Carvajal and Oviedo, 2014), for example: non-starch polysaccharides (PNA) contained in corn. According to Choct et al. (2010), the use of enzymes for poultry neutralizes its effects in cereals, which are not desirable since they increase viscosity, reduce the digestion and absorption of all the nutrients in the diet, especially fat and protein.

On the other hand, Hajati (2010); Khan (2011); Kiarie et al. (2013), found that enzyme complexes promote weight gain and carcass performance, by improving the nutritional value and digestibility of poultry rations, that transform them into low molecular weight products that can pass directly through the intestinal mucosa or are absorbed; furthermore, Cho et al. (2012) observed that enzymes counteract the negative effects caused by the decrease in the concentration of nutrients.
Table 5. Phase two Experiment Weight gain of birds with biological additive (Saccharomyces serevisae + digestive enzymes) in the diet.

\begin{tabular}{cccc}
\hline \multicolumn{1}{c}{ Source } & P-Value & Tukey & Mean value \\
\hline A: Treatment & 0.0471 & T3 & $1,902.09^{\mathrm{a}}$ \\
& & $\mathrm{T} 2$ & $1,777.12^{\mathrm{ab}}$ \\
& & $\mathrm{T} 1$ & $1,731.61^{\mathrm{ab}}$ \\
& & Witness & $1,699.99^{\mathrm{b}}$ \\
B: Sex & 0.0000 & Male & $1,932.92^{\mathrm{a}}$ \\
& & Female & $1,622.48^{\mathrm{b}}$ \\
\hline AB & 0.6078 & & \\
\hline
\end{tabular}

No mortality was recorded during the biological additive inclusion phase (Saccharomyces serevisae + digestive enzymes), according to Guida et al. (2015) S. serevisae has a probiotic function in birds, since they observed that it can agglutinate pathogenic bacterial strains in vitro. This, attributed to the fact that naturally its wall formed by important natural growth promoters ( $\beta$ 1-3 glucan and mannan-proteins) are capable of inhibiting the colonization by pathogens of the digestive tract and adsorb mycotoxins (Zhang and Wang, 2008, Ogbuewu et al. ., 2018). Shareef and AlDabbagh (2009) found that including up to $2 \%$ of Saccharomyces in the diet was enough to achieve a competitive response in the production and mortality parameters, which coincides with that reported by Elghandour et al. (2019) who reported the use of yeast as a probiotic. The use of this yeast in the diet is directly related to the weight gain of the birds, it improves the intestinal mucosa, increases the intestinal villi, thereby increasing the activity of the enzymes secreted by the villi and absorption of nutrients (Arce et al., 2008); however, the development of birds will be affected if the availability of nutrients is correct, Adebiyi et al. (2012) found no differences in the weight of broilers using $1 \%, 1.25 \%$ and $1.5 \%$ 
yeast, although they presented morphological differences such as villus elongation, crypt depth and crypt gland area. in accordance with that described by Reyes et al. (2014) who observed that lower cell wall concentrations than $0.1 \%$, allows better development of organs in birds, increasing the absorption response.

Mortality of up to $6 \%$ (Elghandour et al., In 2019) has been reported in poultry fattening, although the parameters indicate that it should be less than $3 \%$. In the present work, the mortality rate was $0 \%$ with the use of a biological additive that contained Saccharomyces serevisae + digestive enzymes in agreement with the previous author who mentions said yeast as a probiotic and improves the results.

\section{Conclusion}

The use of fly pupae (Anastrepha ludens) and biological additives (Proteases, Lipases, Cellulases, Pectinases, Amylases and Saccharomyces cerevisiae) in rations for poultry (Gallus gallus domesticus), promotes greater weight gain.

Mortality is not influenced by the use of the biological additives used in the experiment.

\section{Literature cited}

Adebiyi, O. A., Makanjuola, B. A., Bankole, T. O., y Adeyori, A. S. (2012). Yeast Culture (Saccharomyces cerevisiae) Supplementation: Effect on the Performance and Gut Morphology of Broiler Birds. Global Journal of Science Frontier Research Biological Sciences, 12: 25-29. https:// cutt.ly/xnsSNVD

Arce, M. J., Ávila, G. E., y López, C. C. (2008). Comportamiento productivo y cambios morfológicos en vellosidades intestinales del pollo de engorda a 21 días de edad con el uso de paredes celulares de Saccharomyces cerevisiae. Notas de investigación. Revista Veterinaria México, 39: 223-228. https://cutt.ly/ansXGyP

Barroso, F. G., Haro, C. de, Sánchez, M. M. J., Venegas, E., Martínez, S. A., y Pérez B. C. (2014). The potential of various insect species for use as food for fish. Aquaculture, 422: 193-201. https://doi.org/10.1016/j. aquaculture.2013.12.024

Bedford, M. R. y Partridge, G. G. (2001). Enzymes in farm animal nutrition. An effect of digestive tract conditions, feed processing and ingredients on response to NSP enzymes. Journal of Animal Physiology and Animal Nutrition, 85, 333-334. https://doi.org/10.1046/j.14390396.2001.0335b.x

Bovera, F., Loponte R., Marono S., Piccolo, G., Parisi G., Laconisi, V., y Nizza, A. (2016). Use of larvae meal as protein source in broiler diet: Effect on growth performance, nutrient digestibility, and carcass and meat traits. Journal of Animal Science, 94, 639-647. https://doi.org/10.2527/ jas.2015-9201

Carvajal, J. J. G., y Oviedo O. E. (2014). Efecto de una serina proteasa en las dietas con el aumento de los niveles de inclusión de sorgo en el rendimiento y la digestibilidad de nutrientes en pollos de engorde. Revista Colombiana de Ciencia Animal, 7: 43-54. https://cutt.ly/ nns $1 \mathrm{yDy}$

Cho, J. H., Zhao, P., y Kim, I. (2012). Effects of Emulsifier and Multi-enzyme in Different Energy Densitydiet on Growth Performance, Blood Profiles, and Relative Organ Weight in Broiler Chickens. Journal of Agricultural Science, 4, 161-168. https://doi.org/10.5539/JAS.V4N10P161

Choct, M., Y. Dersjant-Li, J. McLeish, M. Peisker. 2010. Soy oligosaccharides and soluble non-starch polysaccharides: a review of digestion, nutritive and anti-nutritive effects in pigs and poultry. Asian-Australas. J. Anim. Sci. 23(10): 1386-1398. https://cutt.ly/Fns1CrZ

De Marco, M., Martínez, S., Hernandez, F., Madrid, J., Gai, F., Rotolo, L., Belforti, M., Bergero, D., Katz, H., Dabbou, S., Kovitvadhi, A., Zoccarato, I., Gasco, L., y Schiavone, A. (2015). Nutritional value of two insect larval meals (Tenebrio molitor and Hermetia illucens) for broiler chickens: Apparent nutrient digestibility, apparent ileal amino acid digestibility and apparent metabolizable energy. Animal Feed Science and Technology, 209, 211-218. https://cutt.ly/Wns19Lo

Dalólio, F. S., Moreira, J., Vaz, D. P., Albino, L. F. T., Valadares, L. R., Pires, A. V. y Pinheiro S. R. F. (2016). Exogenous enzymes in diets for broilers. Revista Brasileira de Saúde e Produção Animal, 17, 149-161. https://doi.org/10.1590/S1519-99402016000200003

Elghandour, M., Tan, Z., Abu Hafsa, S., Adegbeye, M., Greiner, R., Ugbogu, E., Cedillo Monroy, J. y Salem, A. (2020). Saccharomyces cerevisiae as a probiotic feed additive to non and pseudo-ruminant feeding: a review. Journal of Applied Microbiology, 128, 658-674. https://doi. org/10.1111/jam.14416

FAO. (2015). Food and agricultural organization. Panorama de la inseguridad alimentaria en América latina y el Caribe. https://cutt.ly/gns011M

FAO. (2013). Food and agricultural organization. Disponibilidad de piensos para aves en países en desarrollo. https://cutt.ly/pns0mx5

Hajati, H. (2010). Effects of Enzyme Supplementation on Performance, Carcass characteristics, Carcass Composition and Some Blood Parameters of Broiler Chicken. American Journal of Animal and Veterinary Sciences, 5, 221-227. https://doi.org/10.3844/ajavsp.2010.221.227

Hassanein, S.M., y Soliman, N.K. (2010). Effect of probiotic (Saccharomyces cerevisiae) adding to diets on intestinal microflora and performance of Hy-line layers hens. Journal of American Science, 6, 159-169. https:// doi.org/10.7537/marsjas061110.21

Hristakieva, P., Mincheva, N., Oblakova, M., Lalev, M., e Ivanova, I. (2014). Effect of genotype on production traits in broiler chickens. Journal of Animal Science, 47, 19-24. https://cutt.ly/Vns0TPk

Hwangbo, J., Hong, E.C.,Jang, A., Kang, H.K., Oh, J.S., Kim, B.W., Park, B.S. (2009). Utilization of house fly-maggots, a feed supplement in the production of broiler chickens. Journal of Environmental Biology, 30, 609-614. PMID: 20120505.

Hwangbo, J., Hong, E. C., Jang, A., Kang, H. K., Oh, J. S., Kim B. W., y Park, B. S. (2009). Utilization of house fly-maggots, a feed supplement in the production of broiler chickens. Journal of environmental biology, 30 , 609-614. PMID: 20120505 https://cutt.ly/Tns9AHc

Józefiak, D. y Engberg, R.M. (2015). Insects as poultry feed. In: Světová drůbežářská vědecká společnost., \& Světová drůbežářská vědecká společnost. (Eds.). Proceedings: 20th European Symposium on Poultry Nutrition : 24-27 August 2015, Prague, Czech Republic. https://cutt. $\mathrm{ly} / \mathrm{Zns} 9 \mathrm{FOu}$

Kouřimská, L., y Adámková, A. (2016). Nutritional and sensory quality of edible insects. Nutrition and Food Science Journal, 4, 22-26: https:// doi.org/10.1016/j.nfs.2016.07.001

Khan, S. H., Atif, M., Mukhtar, N., Rehman, A., y Fareed, G. (2011). Effects of supplementation of multi-enzyme and multi-species probiotic on production performance, egg quality, cholesterol level and immune system in laying hens. Journal of Applied Animal Research, 39, 386398. https://doi.org/10.1080/09712119.2011.621538

Kiarie, E., Romero, L.F., y Nyachoti, C.M. (2013). The role of added feed enzymes in promoting gut health in swine and poultry. Nutrition Research Review, 26, 71-88. PMID: 23639548 https://doi.org/10.1017/ S0954422413000048

Kiros, T.G, Gaydos, J., Corley, R., Berghaus, R., y Hofacre, C. (2019). Effect of Saccharomyces cerevisiae yeast products in reducing direct colonization and horizontal transmission of Salmonella Heidelberg in broilers. Journal of Applied Poultry Research, 28, 23-30. https://doi. org/doi.org/10.3382/japr/pfy012

González, A. J. M., Jiménez, M. E., González, S. D., Lázaro, R., Mateos, G. G. (2010). Effect of inclusion of oat hulls and sugar beet pulp in the diet on productive performance and digestive traits of broilers from 1 to 42 days of age. Animal Feed Science Technology, 162, 37-46. https://doi. org/10.1016/j.anifeedsci.2010.08.010

Guida, N., Mesplet, M., Kotsias, F., González, S., Bustos, C., Laiño, M., Franco, P., Picos, J., y Mascolo, M. (2015). Evaluación del efecto de Saccharomyces cerevisiae sobre E. coli en la cría de pollos. Revista Electrónica de Veterinaria, 16, 1-8. https://cutt.ly/Tns3aDx

Medina, L. S. 2012. El huerto familiar del sureste de México. In perfil productivo y problemática sanitaria en la cría de animales domésticos en hogares campesinos e indígenas de Chiapas. 1ra ed. Mariaca, R. M. p.245-267.

Méndez D., A. D., Cortes C., A. C., Fuente M., B., López C., C. y Ávila C., E. (2009). Efecto de un complejo enzimático en dietas sorgo+soya sobre la digestibilidad ileal de aminoácidos, energía metabolizable y productividad en pollos. Técnica Pecuaria en México, 47(1), 15-25. https://cutt.ly/6ns3jEJ

Mulisa Faji Dida. (2016). Review Paper on Enzyme Supplementation in Poultry Ration. International Journal of Bioorganic Chemistry, 1, 1-7. https:// cutt.ly/GnRzvPr

National Research Council. 1984. Nutrient Requirements of Poultry: Eighth Revised Edition. Washington, DC: The National Academies Press. https://doi.org/10.17226/19397

Nmx-f-083-1986. Alimentos. Determinación de humedad en productos alimenticios. Norma Mexicana. https://cutt.ly/Ans31UE

Nmx-f-066-s-1978. Determinación de cenizas en alimentos. Norma Mexicana. https://cutt.ly/9ns34k9

Nmx-f-089-s-1978. Determinación de extracto etéreo (método soxhlet) en alimentos. Norma mexicana. https://cutt.ly/Xns3783

NOM-F-68-S-1980. Alimentos Determinación de Proteínas. Norma Oficial Mexicana. https://cutt.ly/gns3615

NOM-F-90-S-1978. Determinación de Fibra Cruda en Alimentos. Norma oficial mexicana. https://cutt.ly/qns8wlh

Ogbuewu I. P, Okoro, V. M, Mbajiorgu, E. F, y Mbajiorgu, C. A (2018). Yeast (Saccharomyces cerevisiae) and its effect on production indices of livestock and poultry - a review. Comparative Clinical pathology. PP 1-9: https://doi.org/10.1007/s00580-018-2862-7 
6-6| Rev. Fac. Agron. (LUZ). 2022, 39(1): e223903. January - March. ISSN 2477-9407.

Oonincx, D. G. A. B. y Finke, M. D. (2020). Nutritional value of insects and ways to manipulate their composition. Journal of Insects as Food and Feed. ISSN 2352-4588 online, https://doi.org/10.3920/JIFF2020.0050

Pieterse, E. y Pretorius, Q. (2014). Nutritional evaluation of dried larvae and pupae meal of the housefly (Musca domestica) using chemical-and broiler-based biological assays. Animal Production Science, 54, 347-355. https://doi. org/10.1071/AN12370

Pretorius, Q. (2011). The evaluation of larvae of Musca domestica (common house fly) as protein source for broiler production. Doctoral dissertation. Stellenbosch, Stellenbosch University. https://cutt.ly/Uns8iqS

Reyes, S. N., Piad, B. R., González, N. H. D. y Ríos, M. (2014). Rendimiento de la canal y morfometría del tracto gastrointestinal de broilers suplementados con pared celular de levadura. Revista Cientifica La Calera, 14, 33-37. https://cutt.ly/wns8acd

Romero, M. H., J. A. Sánchez, J. F. Moncayo. (2014). Evaluación de la mortalidad y de las lesiones traumáticas en pollo de engorde bajo condiciones de sacrificio comercial. Rev. Biosalud, 13(1): 30-36. https://cutt.ly/7ns8fw5

Rumpold, B. A., y Schlüter, O. K. (2013). Nutritional composition and safety aspects of edible insects. Molecular Nutrition \& Food Research, 57, 802823. PMID: 23471778 https://doi.org/10.1002/mnfr.201200735

Schiavone, A., De Marco, M., Martínez, S., Dabbou, S., Renna, M., Madrid, J., Hernández, F., Rotolo, L., Costa, P., Gai, F., y Gasco, L. (2017). Nutritional value of a partially defatted and a highly defatted black soldier fly larvae (Hermetia illucens L.) meal for broiler chickens: apparent nutrient digestibility, apparent metabolizable energy and apparent ileal amino acid digestibility. Journal of Animal Science Biotechnology, 8, 1-9. PMID: 28603614 PMCID: PMC5465574 https://doi.org/10.1186/s40104017-0181-5

SAGARPA. 2015. Secretaría de Agricultura, Ganadería, Desarrollo Rural, Pesca y Alimentación. Proyecciones para el Sector Agropecuario de México, 09-18. https://cutt.ly/Pns8kEA
SAGARPA. 2007. Secretaría de Agricultura, Ganadería, Desarrollo Rural, Pesca y Alimentación. Programa Especial para la Seguridad Alimentaria, 2-10.

Sánchez, S., y Torres, R. J. (2013). Diagnóstico y tipificación de unidades familiares con y sin gallinas de traspatio en una comunidad de Huatusco, Veracruz (México). Avances en Investigación Agropecuaria, 16, 64-74. https://cutt.ly/Ens85N8

Sancho, D., Fernández, L. S., y Álvarez, M. G. (2015). Insectos y alimentación. Larvas de Rhynchophorus palmarum L, un alimento de los pobladores de la Amazonía Ecuatoriana. Entomotropica 30, 135-149. https:/cutt. ly/7ns4wfT

SEDESOL. Secretaría de Desarrollo Social del Gobierno de la República Mexicana. 2010. https://cutt.ly/Sns4txG

Shareef, A. M., y Al-Dabbagh, A. S. A. (2009). Effect of probiotic (Saccharomyces cerevisiae) on performance of broiker. Iraqi Journal Veterinary Science, 23, 23-29. Proceedings of the $5^{\text {th }}$ Scientific Conference, College of Veterinary Medicine, University of Mosul https://cutt.ly/Hns4iO7

UNA. 2015. Unión Nacional de Avicultores. Situación de la avicultura en México. https://cutt.ly/undtCWn

USDA. 2015. United States Department of Agriculture. Panorama agroalimentario del maíz. 3-26. https://cutt.ly/kndtZ4V

Veldkamp, T., Van Duinkerken, G., Van Huis, A., Lakemond, C., Ottevanger, E., Bosch, G., y Van Boekel, T. (2012). Insects as a Sustainable Feed Ingredient in Pig and Poultry Diets: a Feasibility Study. No. 638. Wageningen UR Livestock Research. Netherlands. https://cutt.ly/Kndyszq

Van Huis, A., Van Itterbeeck, J., Klunder, H., Mertens, E., Halloran, A., Muir, G., y Vantomme, P. (2013). Edible insects: future prospects for food and feed security. Rome, Italy. 171: 123-125. https://cutt.ly/8ndoeHo

Zhang, B., Guo, Y., y Wang, Z. (2008). The modulating effect of beta-1, 3/1, 6-glucan supplementation in the diet on performance and immunological responses of broiler chickens. Asian Australas. Journal of Animal Science, 21, 237-244. https://cutt.ly/MndyvYm 